\title{
STUDI MORFOLOGI DAN FENETIK TAKSONOMI IKAN INTRODUKSI KHAS TELAGA SARI, PASURUAN
}

\section{Morphological Studies and Phenetics Taxonomy of Typical Introduced Fishes in Sari Lake, Pasuruan}

\author{
Dwi Anggorowati Rahayu ${ }^{\mathrm{a} *}$, Endik Deni Nugroho ${ }^{\mathrm{b}}$, Dwi Listyorini ${ }^{\mathrm{c}}$
}

\author{
${ }^{1}$ Jurusan Biologi, FMIPA, Universitas Negeri Surabaya, Jawa Timur, Indonesia \\ ${ }^{2}$ Jurusan Pendidikan Biologi, FKIP, Universitas Borneo Tarakan, Kalimantan Utara, Indonensia \\ ${ }_{3}^{3}$ Jurusan Biologi, FMIPA, Universitas Negeri Malang Jawa Timur, Indonesia \\ *Corresponding author: dwirahayu@unesa.ac.id
}

\begin{abstract}
Anggota Famili Poeciliidae merupakan ikan introduksi dengan karakteristik berukuran kecil, live-bearers, dimorfi seksual dari segi ukuran tubuh, pola warna dan struktur gonopodium sebagai ciri diagnostik pada ikan jantan. Ikan ini berperan sebagai pengontrol perkembangan nyamuk malaria dan model pembelajaran biologi. Sejauh ini kajian taksonomi dan penelusuran hubungan kekerabatan didalam famili Poeciliidae belum ada. Tujuan penelitian ini adalah mengidentifikasi jenis, kekerabatan dan pengelompokkan berdasarkan karakter morfologi (morfometrik, meristrik, gonopodium dan ciri diagnostiknya). Jenis penelitian ini adalah deskriptif eksploratif, dengan pendekatan survey. Pada penelitian ini ditemukan tiga spesies ikan Poeciliidae yaitu Xiphoporus helleri, Poecilia mexicana dan Poecilia reticulata. Dendogram hasil analisis morfologi menggunakan metode UPGMA diperoleh dua kelompok percabangan apomorfi yaitu kelompok Genus Xiphoporus dan Genus Poecilia. Sub Clade automorfi antara Xiphoporus helerri A dan B dengan nilai kesamaan 92\%. Pengelompokkan ikan Poeciliidae dibedakan berdasarkan lima karakter utama terpilih yaitu: SL (standart length), Hdl (Panjang kepala), Panjang gonopodium, panjang sirip ekor dan PreDL (Panjang sebelum sirip dorsal).Kejelasan identifikasi ikan introduksi khas Telaga Sari menjadi modal utama dalam aquaculture, manajemen, konservasi, biodiversitas dan perkembangan ilmu pengetahuan.
\end{abstract}

Kata kunci: morfologi, fenetik taksonomi, Poeciliidae, biodiversitas, penggelompokkan

\begin{abstract}
Poeciliidae family are small-sized introduced fish, live-bearers, have sexual dimorphy of body size, color patterns and gonopodium structures as a diagnostic characteristic in male fish. This fish acts as a development controller of malaria mosquitoes and as learning models in biological studies. So far, the taxonomy study and their relationship not available. The purposes of this study were to identify the species, relationship and grouping based on morphological characters (morphometrics, meristrics, gonopodium and diagnostic characteristics). The type of this research is descriptive explorative, with a survey approach. In this study, we are found three species of Poeciliidae. They are: Xiphoporus helleri, Poecilia mexicana and Poecilia reticulata. Dendogram showed that based on morphological analysis using the UPGMA method obtained two apomorphic grouped, namely the Genus Xiphoporus and Genus Poecilia groups. Sub Clade
\end{abstract}

Citation: Rahayu, DA., Nugroho, E.D \& Listyorini, D. (2019). Studi Morfologi dan Fenetik Taksonomi ikan Introduksi Khas Telaga Sari, Pasuruan. Borneo Journal of Biology Education, 1(1), 1-20.

DOI: 


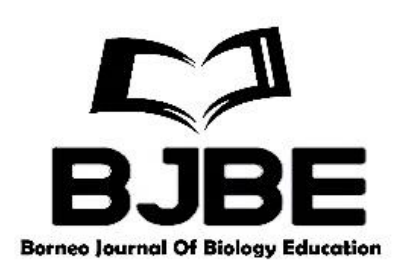

Automorph between Xiphoporus helerri A and B with 92\% similarity value. Poeciliidae grouped were distinguished based on the five main selected characters, namely: SL (standard length), Hdl (head length), gonopodium length, sub distal protrusion of gonopodium and PreDL (pre dorsal lenght).The corret identification of fish species is a main useful tool for aquaculture, biodiversity, management, conservation and development of science.

Keywords : morphology, phenetics taxonomy, Poeciliidae, biodiversity, grouping

\section{Pendahuluan}

Telaga Sari Purwodadi, Kabupaten Pasuruan merupakan telaga kecil yang terletak di desa Sentul, Purwodadi, Kabupaten Pasuruan. Telaga Sari memiliki beraneka ragam ikan introduksiyang melimpah keberadaannya. ikan tersebut yaitu ikan anggota Famili Poeciliidae. Anggota famili Poeciliidae terdiri dari 3 sub famili, yaitu Poeciliinae (220 spesies), Procatopodinae (78 spesies), dan Aplocheilichthyinae (1 spesies) (Lucinda, 2013). Famili Poeciliidae merupakan ikan yang tersebar luas hampir di seluruh belahan dunia mulai dari Afrika, China, Turki, Prancis, Mexico, Inggris, Vietnam, Malaysia, Spanyol, Portugis, Belanda, Denmark, Polandia, Rusia, Albania, dan Jepang, termasuk di Indonesia (Tamaru \& Bailey, 2001). Ikan Poeciliidae merupakan ikan Endemik khas negara Amerika, Australia Mexico, dan Kanada (Canoniko et al., 2005; Litermans, 2004). Saat ini, di Indonesia keberadaan ikan ini melimpah ruah. Penyebaran ikan introduksi/asing ke dalam suatu wilayah merupakan salah satu penyebab utama ancaman keanekaragaman ikan di alam (Lee, 2002; Semeens et al., 2004; Dudgeonet al., 2004) terutama ikan-ikan yang mendiami perairan tawar seperti ekosistem danau (Litermans, 2004). Hensen et al. (1981) menyatakan bahwa melimpahnya ikan hias air tawar disinyalir keberadaanya menjadi faktor utama dalam penyebaran ikan introduksi dari satu lokasi ke lokasi lainnya bahkan sebagian dari ikan tersebut telah tercatat sebagai invasive alien species.

Anggota sub famili Poeciliinae yang terkenal di Amerika sebagai ikan hias seperti: ikan guppies, swordtails, mosquito fishes, platys (Lucinda, 2005). Ikan yang termasuk kelompok guppy's yang melimpah di Indonesia diantaranya Poecilia wingei, Poecilia velifera, Poecilia reticulata, Poecilia gracilis, dan Poecilia caucana; ikan swordtails diantaranya Xiphophorus cuocinus, Xiphophorus montezumae, dan Xiphophorus hellerii, sedangkan kelompok ikan mollies yaitu Poecilia mexicana, Poecilia sphenops dan Poecilia latipuncata (Pez, 2009). Karakter diagnostik ikan Famili Poeciliidae yaitu sirip punggung berjumlah satu dengan karakter jari-jari lunak, A9, jari-jari ketiga sirip anal tersebut tidak bercabang, bentuk sirip ekor rounded atau emarginated, V6, P9-16, dimorfi seksual dari segi ukuran tubuh dan pola warna, serta memiliki sisik sikloid (Ghedotti, 2000).

Kemelimpahan ikan introduksi khas di Telaga Sari Purwodadi, Kabupaten Pasuruan menjadikan ikan ini menarik untuk diteliti dari berbagai aspek, baik taksonomi, fisiologi, reproduksi dan kelimpahannnya. Hal ini dikarenakan dalam satu danau yang berukuran kecil hanya ditemukan ikan Famili Poeciliidae tersebut dalam jumlah melimpah dan tidak ditemukan jenis ikan lokal lainnya. Kemelimpahan dan keanekaragaman ikan ini tidak didukung dengan pengenalan masyarakat sekitar terkait potensi dan keberadannya di alam. Rahayu et al. (2010) menyatakan secara genetik berdasarkan gen 16S rRNA ikan introduksi yang berada di Telaga Sari merupakan Famili Poeciliidae, namun belum teridentifikasi sampai tingkat spesies. Hasil penelitian tersebut sangat mengejutkan, hal ini dikarenakan ikan 


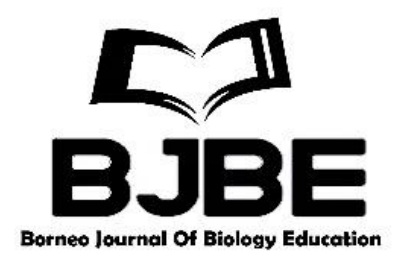

gatul dari Telaga Sari memiliki hubungan kekerabatan yang sangat jauh (outgroup) dengan Poecilia reticulata yang merupakan anggota satu familia yaitu Poeciliidae. Belum diketahui secara pasti status taksonomi ikan introduksi tersebut membuat pentingnya dilaksanakannya penelitian dasar terkait status taksonomi ikan ini dan pengelompokannya dalam upaya pengelolaan, budidaya dan konservasi keberlanjutannya. Dugaan awal susahnya identifikasi ikan introduksi ini dikarenakan adanya fenomena cryptic spesies, sehingga identifikasi ikan tersebut sulit untuk dilakukan.

Tjitrosoepomo (1993) menyatakan bahwa pentingnya mempelajari hubungan kekerabatan diantara spesies ikan dalam suatu perairan adalah memperkenalkan karakter morfologi serta memperkirakan jumlah ikan dalam suatuperairan. Tujuan pengelompokkan tersebut yaitu dapat menggambarkan perubahan yangterjadi pada suatu spesies ikan yang kemungkinandisebabkan oleh faktor-faktor lingkungan perairanmengalami proses perubahan (Tjitrosoepomo, 1993).Adanya fenomena cyptic species dan belum adanya kejelasan ilmiah terkait status taksonomi ikan Famili Poeciliidae di Telaga Sari Pasuruan, maka perlu dilakukan upaya assessment secara cepat melalui identifikasi dan penelusuran hubungan kekerabatan dengan menggunakan marka diagnostik karakter morfologi. Penelitian ini dilakukan untuk mengidentifikasi jenis ikan introduksi Famili Poeciliidae melalui identifikasi morfologi meliputi karakter morfometrik, meristrik, diagnostik, struktur gonopodium dan ciri diagnostik lainnya serta menggelompokkannya berdasarkan hubungan kekerabatannya.

\section{Material dan metode}

Penelitian ini merupakan penelitian deskriptif eksploratif. Objek yang digunakan dalam penelitian ini yaitu ikan Famili Poeciliidae yang ditemukan di Telaga Sari, Purwodadi, Kabupaten Pasuruan. Lokasi telaga Sari terletak di Desa Sentul, Purwodadi, Kabupaten Pasuruan (Gambar 1). Ikan Famili Poeciliidae yang tertangkap dalam jaring akan dimasukkan kedalam alkohol $70 \%$ untuk selanjutnya diamati di Laboratorium Taksonomi. Penelitian ini menggunakan metode survei dengan teknik pengambilan sampel secara Purposive Random Sampling. Sampel berupa ikan Poeciliidae hasil tangkapan di Telaga Sari, Kabupaten Pasuruan.
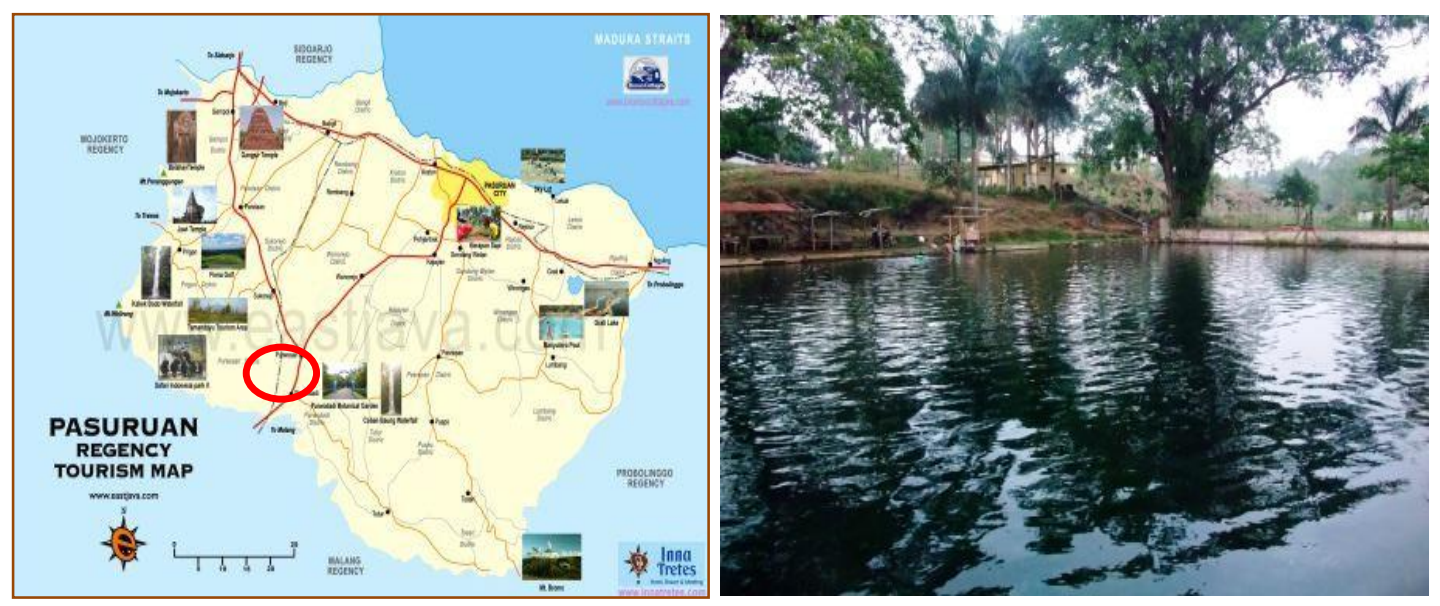

Gambar 1. Peta lokasi telaga Sari, Purwodadi, Kabupaten Pasuruan

Pengambilan ikan famili Poeciliidae dilakukan dengan teknik sebar jala. Ikan yang tersaring dalam jala, kemudian diamati secara singkat terlebih dahulu, jika jantan ukurannya 


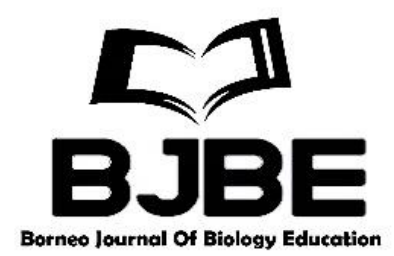

lebih ramping, pola warna lebih bervariasi, serta memiliki modifikasi sirip anal yang disebut gonopodium, sedangkan ikan betina lebih gemuk dan besar, warna tidak bervariasi, dan tidak memiliki gonopodium. Studi karakter morfologi ikan dilakukan dengan mengamati morfometrik, meristrik, pigmentasi dan struktur gonopodium. Bagian-bagian morfometrik ikan yang betina dan jantan yang diukur yaitu: Total length (TL), Standart length (SL), Pre Dorsal Length (PreDL), Pre Orbital Length (PreOL), Pre Pectoral Length (PrePL), Pre Pelvic Length, Pre Anal Length (PreAL), Eye Length (EyeL), panjang bola mata, tinggi badan (body depth), tinggi kepala (head depth), panjang batang ekor (length of caudal peduncle), tinggi batang ekor (depth of caudal peduncle), panjang sirip punggung (length of dorsal fin), panjang sirip anal (length of anal fin), panjang sirip dada (length of pectoral fin), panjang sirip perut(length of pelvic fin), panjang sirip ekor (length of caudal fin), panjang ekor pedang (length of sword), panjang moncong (snout length), tinggi sirip punggung, tinggi sirip dada, tinggi sirip ekor, tinggi sirip perut, tinggi sirip anal (Maurince, 2003), panjang gonopodium (Meyer et al., 2010). Penjelasan morfometrik dapat dilihat pada Gambar 2 dan 3 .

Sampel ikan yang terambil akan dikelompokkan berdasarkan kesamaan morfologinya secara makroskopis, kemudian difoto. Ikan segera dimasukkan ke dalam botol sampel berlabel, kemudian botol diisi larutan alkohol 70\% hingga ikan terendam. Ikan yang telah direndam dicuci dan difiksasi dengan alkohol $70 \%$ dalam botol sampel untuk diidentifikasi. Karakter morfologi sampel yang tertangkap diidentifikasi dan dideterminasi berdasarkan buku pedoman Taksonomi dan Identifikasi Ikan menurut Saanin (1984) dan Kotellat et al. (1993). Bagian meristrik yang diamati yaitu jumlah jari-jari sirip punggung, anal, ekor, dada, abdomen, jumlah sisik lateral (linea lateralis), dan jumlah sisik transversal (linea transversalis). Pigmentasi yang diamati yaitu pada bagian abdomen tubuh dan sirip. Struktur gonopodium yang diamati yaitu: jari-jari ke-3 meliputi kait, ujung segmen, duri batang, blade, retrose serrae, gonopodium palp; jari-jari 4a meliputi: ramus, distal serrae; jari-jari $4 p$ meliputi ujung segmen, proksmial serrae; jari-jari 5a meliputi: cakar, kait; dan jari-jari 5p serta tonjolan sub distal gonopodium (Gordon et al., 1951) (Gambar 4). Karakter anatomi yang diamati yaitu tipe sisik, macam-macam sirip, tipe sirip ekor, jenis jari-jari sirip, tipe tulang ekor, bentuk tubuh ikan, tipe letak mulut, serta ada tidaknya pemanjangan sirip ekor.

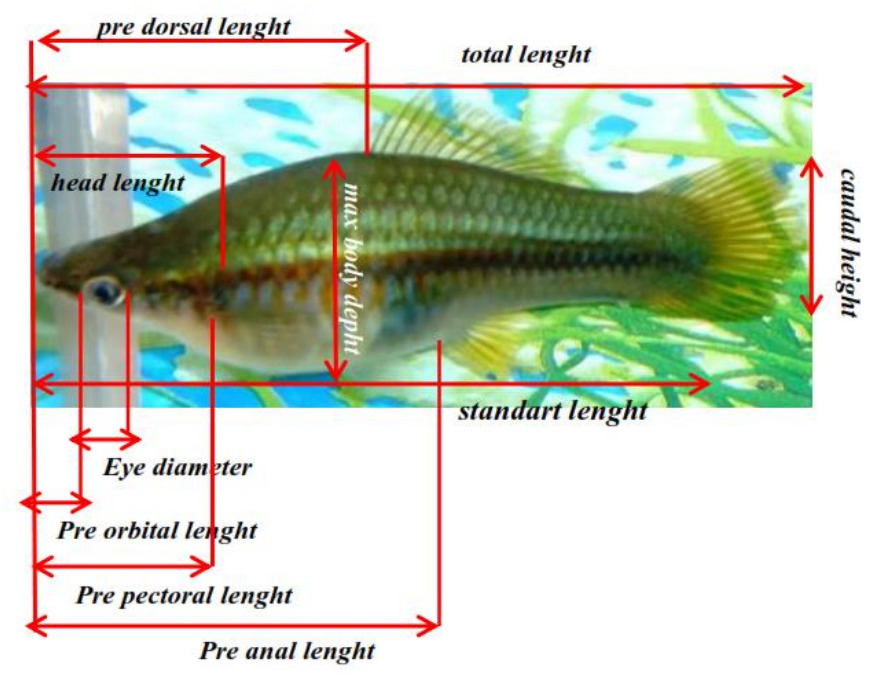

Gambar 2. Karakter morfometrik ikan betina yang diukur 

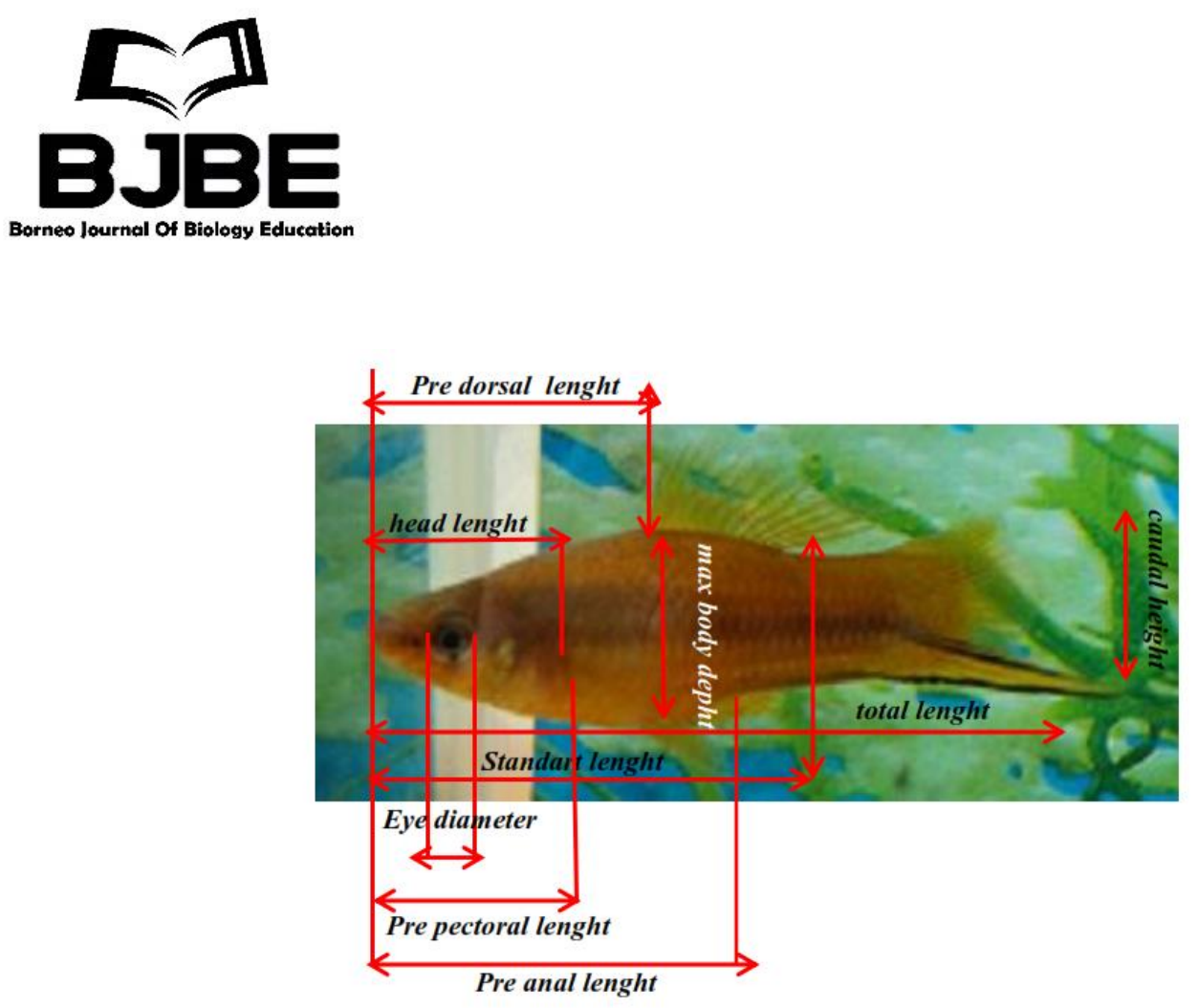

Gambar 3. Karakter morfometrik ikan jantan yang diukur

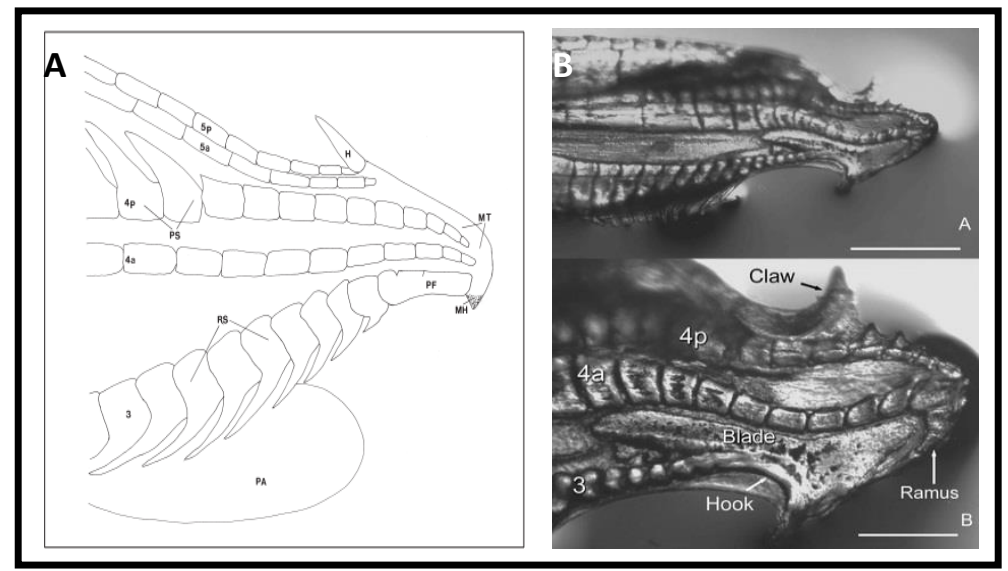

Gambar 4. Struktur Gonopodium A. Poecilia rositae (Meyer et al., 2004), B. Xiphophorus hellerii (Hrbek, 2006)

Pengamatan morfometrik dilakukan dengan menggunakan kertas milimeter blok.Ikan diletakkan di atas milimeter blok, kemudian dihitung jumlah petak dari masing-masing parameter morfometrik yang diamati. Pengamatan pigmentasi tubuh ikan dilakukan untuk mengidentifikasi warna dan pigmentasi yang ada pada permukaan tubuh ikan jantan maupun ikan betina, kemudian memfoto sampel. Pengamatan tipe sisik ikan dilakukan dengan mengambil sisik ikan dari bagian kepala, badan, dan ekor, kemudian diamati strukturnya dengan menggunakan mikroskop. Pengamatan macam sirip dan tipe sirip ekor, dilakukan dengan cara mengamati bentuk sirip ekor, pemanjangan sirip ekor, serta penghitungan jumlah jari-jari sirip punggung. Pengamatan struktur gonopodium dilakukan dengan memotong bagian gonopodium, kemudian mengamati struktur tersebut dengan menggunakan mikroskop BX51.

Hubungan kekerabatan fenetik pada spesies ikan Famili Poeciliidae yang telah diidentifikasi sebagai berikut: a) Menentukan Satuan Taksonomi Operasional spesies ikan Faimili Poeciliidae yang dibandingkan; b) Menyeleksi karakter morfologi dari masing- 


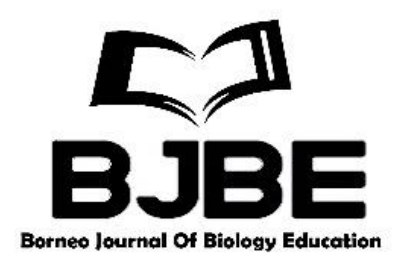

masing sampel yang dapat dibandingkan untuk memberi gambaran secara umum dari ciri satuan taksonomi operasional yang dinyatakan dengan kode- kode biner. Kode tersebut yaitu: angka 1 untuk karakter yang dimiliki dan apabila tidak terdapat karakter yang dimiliki diberi angka 0 ; c) Menyusun data ciri-ciri morfologi ke dalam bentuk tabel atau matriks untuk semua spesies yang dikarakterisasi; d) Data yang diperoleh selanjutnya dianalisis dengan menggunakan NTSYS 2.02i. Data yang diperoleh dari hasil identifikasi dan determinasi berdasarkan Kottelat et al. (1993) dan (Gordon et al., 1951) dihitung analisis hubungan kekerabatannya dengan menggunakan koefisien asosiasi antar spesies (S) dan metode UPGMA Cluster Analysis melalui program Numerical TaxonomySystem (NTSYS) versi $2.02 \mathrm{i}$

\section{Hasil dan Diskusi}

\section{Deskripsi ikan Famili Poeciliidae yang ditemukan}

Ikan Famili Poeciliidae yang ditemukan dari Telaga Sari, Purwodadi Kabupaten Pasuruan diidentifikasi berdasarkan Kottelat et al. (1993) dan Gordon et al (1951) diperoleh sebanyak 100 ikan, terdiri atas 3 jenis, diantaranya: 30 ikan Xiphoporus sp. Abu-abu, 20 ikan Xiphoporus sp. oranye, 20 ikan Poecilia sp. besar, dan 30 ikan Poecilia sp. kecil. Karakter umum anggota famili Poeciliidae yaitu berukuran kecil (panjang total antara 4-20 cm), dengan karakter utama yaitu (1) jari- jari ke 3, 4, dan 5 dari sirip anal mengalami modifikasi menjadi gonopodium (Lucinda, 2003); (2) fertilisasinya secara internal (ikan jantan memasukkan sperma ke dalam organ regenital betina); (3) bunting dan melahirkan (live bearers) (Parenti, 1981; Lucinda, 2003). Spesies dominan ditemukan yaitu Xiphoporus sp.

Genus Xiphoporus Karl Bartholomaeus Heller 1824 Xiphoporus helleri Heckel 1848

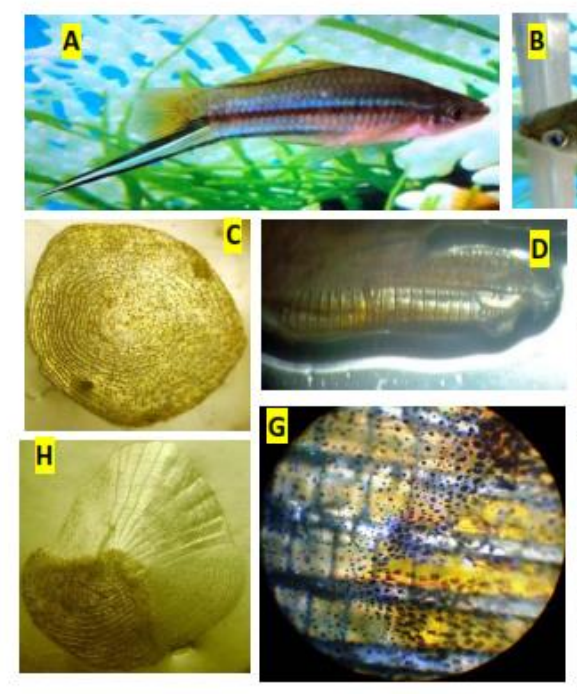

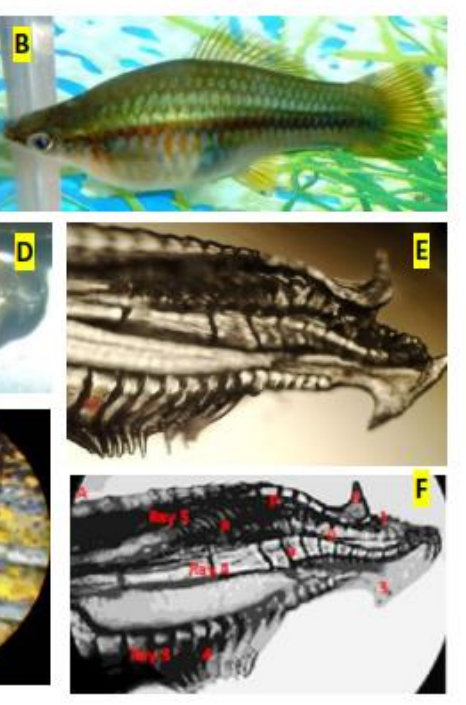

Gambar 5.Xiphoporus helleri, SL = $43 \mathrm{~mm}, \mathrm{SL}=64 \mathrm{~mm}$, Telaga Sari, Purwodadi Kabupaten Pasuruan. Keterangan: A. Ikan Jantan, B. Ikan Betina, C. Sisik sikloid abdomen, D. Gonopodium jantan, E \& F Struktur Gonopodium, G. pigmentasi jantan, H. Sisik sikloid daerah sirip ekor

\section{Karakteristik}

Jumlah jari-jari sirip punggung D14-15 (jari-jari ke 1 dan 3 tidak bercabang) (Gb 5B); jumlah jari-jari sirip dada P12-13 (jari-jari 1 dan terakhir tidak bercabang) (Gb 5A); jumlah jari-jari sirip anal ikan betina A9; jumlah jari-jari sirip ekor C26-32; jumlah jari-jari sirip perutV6; jumlah sisik lateral LL 26-28; dan jumlah sisik transversalis Ltr 4 1/2 1.3 1/2. Karakter anatomi yang dimiliki oleh ikan Xiphoporus sp. abu-abu ini sebagai berikut: tipe sirip ekor membulat (rounded); jenis jari-jari sirip lunak; tipe sisik sikloid (Gb 5C): sisik pada bagian kepala memiliki hanya garis kosentris $(\mathrm{Gb} 5 \mathrm{H})$, sisik pada bagian abdomen memiliki 


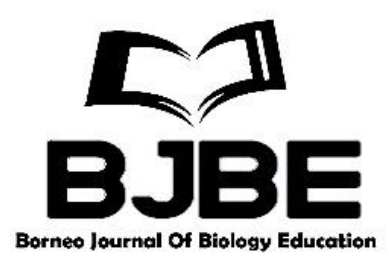

garis konsentris dan radier (Gambar 5H); tipe tulang ekor ikan isosercal; bentuk tubuh ikan compressed; tipe letak mulut superior; posisi awal sirip dorsal ikan betina lebih awal daripada sirip anal; posisi awal sirip punggung setengah dari sirip dada; ikan jantan memiliki pemanjangan sirip ekor berbentuk pedang pada bagian ventral. Bentukan ini berwarna hitam keabu-abuan.

\section{Pola Warna:}

Warna tubuh abu-abu kehitaman. Pigmentasi abdomen dan sirip baik pada ikan jantan maupun ikan betina memiliki banyak pigmen karotenoid yang memberikan warna kuning, pteridine memberikan warna oranye, dan sedikit pigmen melanosit yang memberikan warna hitam. Ikan Xiphoporus sp. Abu-abu memiliki garis lateral berwarna merah kecoklatan yang merupakan pigmen karotenoid dan pteridine.

\section{Distribusi:}

Spanyol, Portugis, Belanda, Denmark, Telaga Sari, Purwodadi, Kabupaten Pasuruan

\section{Genus Xiphoporus Karl Bartholomaeus Heller 1824 \\ Xiphoporus helleri Heckel 1848}
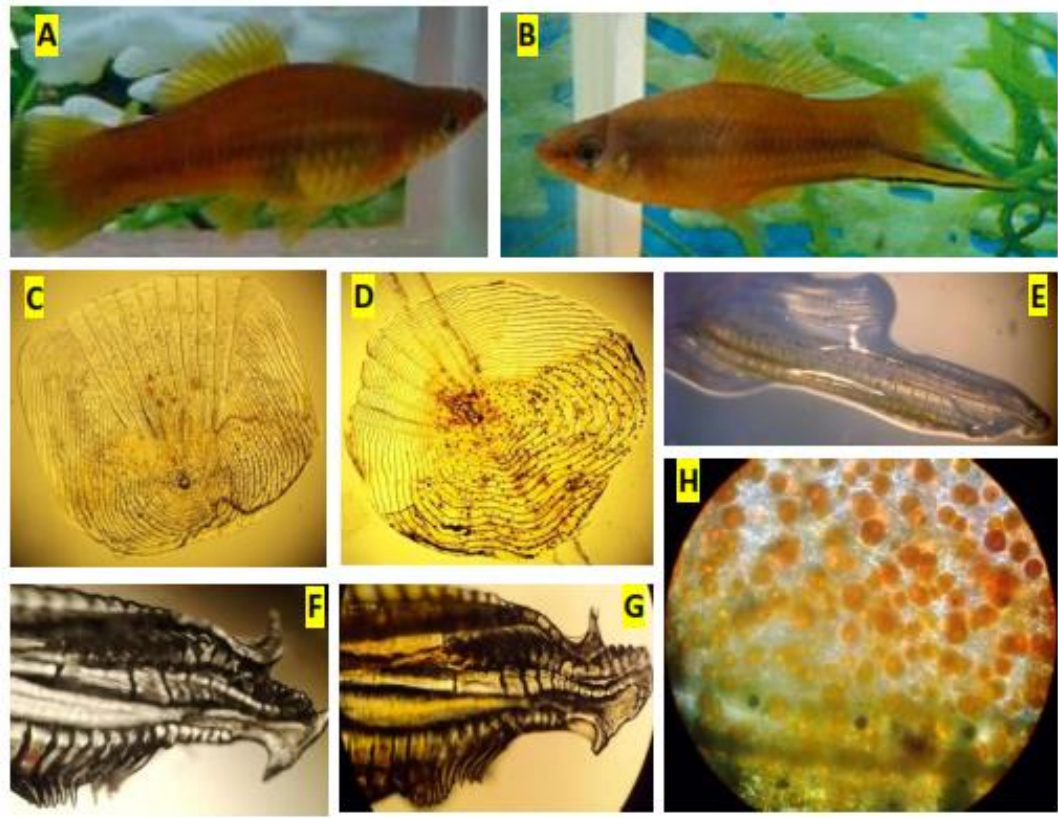

Gambar 6.Xiphoporus helleri, $\mathrm{SL}=46 \mathrm{~mm}$, SL $=78 \mathrm{~mm}$, Telaga Sari, Purwodadi Kabupaten Pasuruan. Keterangan: A. Ikan Betina, B. Ikan Jantan, C. Sisik sikloid abdomen, D. Sisik sikloid daerah sirip ekor, E. Gonopodium ikan jantan, F \& G Struktur Gonopodium, H. Pigmentasi jantan

\section{Karakteristik}

Jumlah jari-jari sirip punggung D14-15 (jari-jari ke 1 dan 3 tidak bercabang) (Gambar 6A); jumlah jari-jari sirip dada P12-13 (jari-jari 1 dan terakhir tidak bercabang); jumlah jarijari sirip anal ikan betina A9; jumlah jari-jari sirip ekor C26-32; jumlah jari-jari sirip perutV6; jumlah sisik lateral LL 26-28; dan jumlah sisik transversalis Ltr 4 1/2 1.3 1/2. Karakter anatomi yang dimiliki oleh ikan Xiphoporus sp. oranye ini sebagai berikut: tipe sirip ekor membulat (rounded); jenis jari-jari sirip lunak; tipe sisik sikloid (Gb 6C): sisik pada 


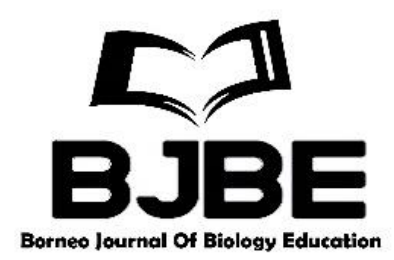

bagian kepala memiliki hanya garis kosentris (Gb 6D), sisik pada bagian abdomen memiliki garis konsentris dan radier (Gambar 6D); tipe tulang ekor ikan isosercal; bentuk tubuh ikan compressed; tipe letak mulut superior; posisi awal sirip dorsal ikan betina lebih awal daripada sirip anal; posisi awal sirip punggung setengah dari sirip dada; ikan jantan memiliki pemanjangan sirip ekor berbentuk pedang pada bagian ventral. Bentukan ini berwarna oranye.

\section{Pola Warna}

Pigmentasi abdomen dan sirip baik pada ikan jantan maupun ikan betina memiliki banyak pigmen karotenoid yang memberikan warna kuning, pteridin memberikan warna oranye, dan sedikit pigmen melanosit yang memberikan warna hitam. Ikan jenis 1 memiliki garis lateral berwarna merah kecoklatan yang merupakan pigmen karotenoid dan pteridin.

\section{Distribusi:}

Spanyol, Portugis, Belanda, Denmark, Telaga Sari, Purwodadi, Kabupaten Pasuruan

Genus Poecilia Bloch \& J. G. Schneider, 1801

Poecilia mexicana Steindachner, 1863
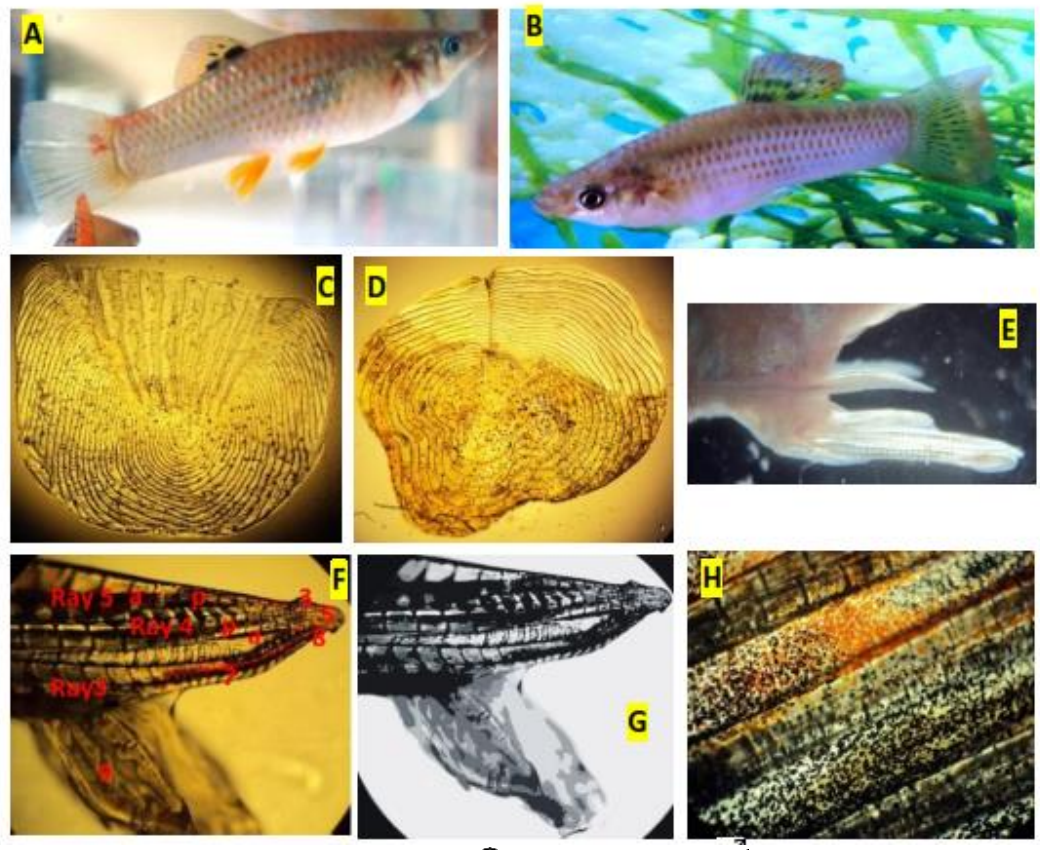

Gambar 7.Xiphoporus helleri, $, \mathrm{L}=46 \mathrm{~mm}, \mathrm{O}^{7},=78 \mathrm{~mm}$, Telaga Sari, Purwodadi Kabupaten Pasuruan. Keterangan: A. Ikan Betina, B. Ikan Jantan, C. Sisik sikloid abdomen, D. Sisik sikloid daerah sirip ekor, E. Gonopodium ikan jantan, F \& G Struktur Gonopodium, H. Pigmentasi jantan

\section{Karakteristik:}

Jumlah jari-jari sirip punggung D10-11 (jari-jari ke 1 dan 2 tidak bercabang) (Gb 7A); jumlah jari-jari sirip dada P12-14 (jari-jari 1 dan terakhir tidak bercabang); jumlah jari-jari sirip anal ikan betina A9-10 (Jari-jari 1 dan terakhir tidak bercabang); jumlah jari-jari sirip ekor C2628; jumlah jari-jari sirip perut V6, jari-jari ke-5 lebih panjang dan bengkok; jumlah sisik lateral LL 25-32; dan jumlah sisik transversalis Ltr 3 1/2.1.4 1/2. Karakter anatomi ikan jenis 3 sebagai berikut: bentuk sirip ekor truncate (bersegi) (Gb.7B); tipe sisik sikloid (Gb 7B): pada 


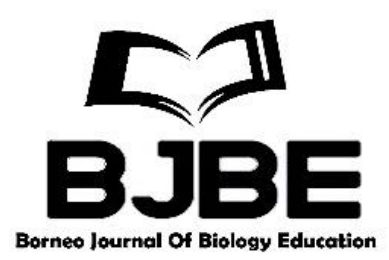

bagian kepala hanya memiliki garis konsentris $(\mathrm{Gb} 7 \mathrm{C})$ pada bagian abdomen memiliki garis konsentris dan garis radier (Gb.7C); Tipe jari-jari sirip lunak; tipe tulang ekor ikan isosercal; bentuk tubuh ikan compressed; tipe letak mulut superior; posisi sirip punggung lebih awal daripada sirip anal; sirip punggung berbentuk rounded; posisi sirip perut lebih awal daripada sirip anal.

\section{Pola Warna:}

Bagian abdomen dan sirip ikan jantan dan betina memiliki banyak pigmen karotenoid yang memberikan warna kuning, sedikit pteridin yang memberikan warna oranye, dan sedikit pigmen melanosit yang memberikan warna hitam. Adanya spot oranye didaerah abdomen, terlihat rapi dan berderet antero-posterior mengikuti tata letak sisik. Pada ekor ikan jantan terdapat pola warna seperti batik yang dibentuk oleh spot melanosit, smear karotenoid dan pteridine.

\section{Distribusi:}

Polandia, Rusia, Albania, dan Jepang, Telaga Sari, Purwodadi, Kabupaten Pasuruan

\section{Genus Poecilia Bloch \& J. G. Schneider, 1801 Poecilia reticulata Peters, 1859}

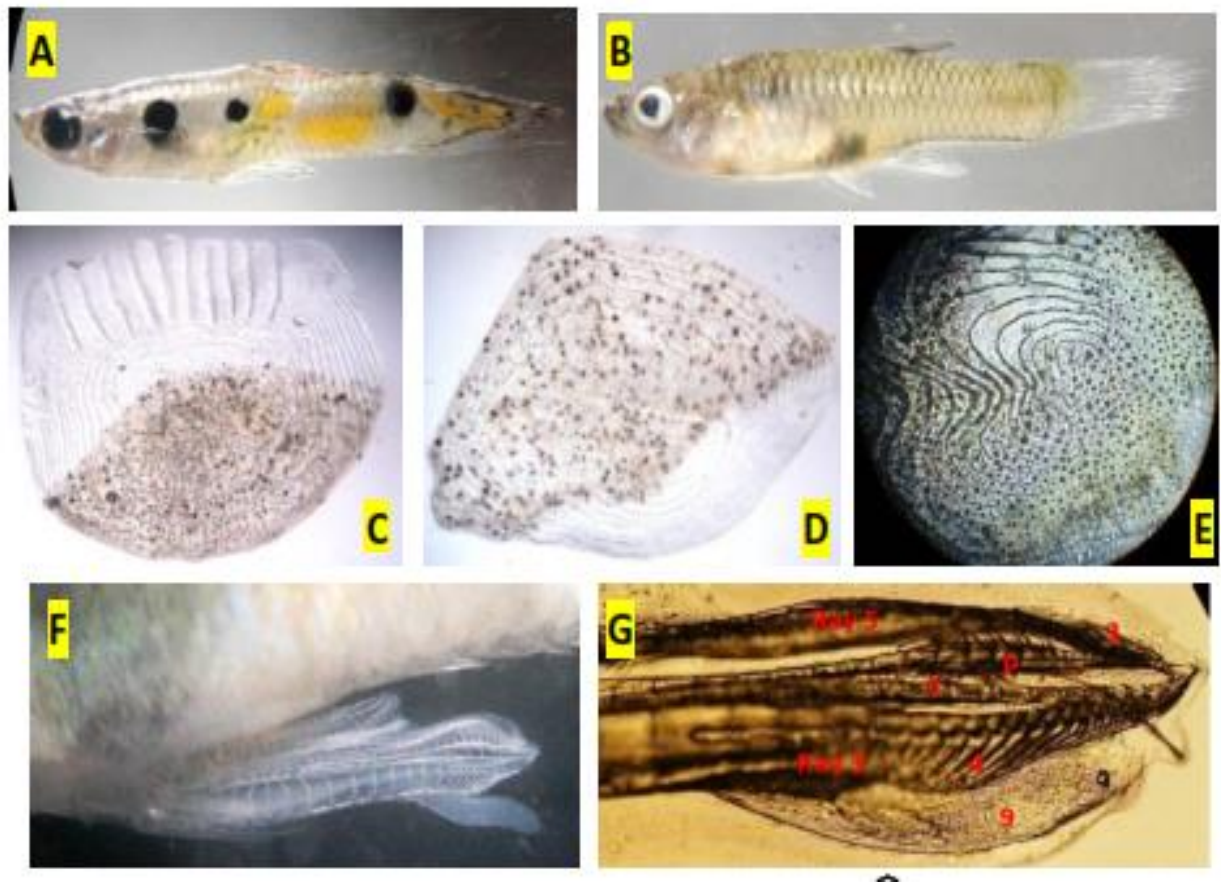

Gambar 8.Poecilia reticulata, SL $O^{7}=55 \mathrm{~mm}$, SL $Q=72 \mathrm{~mm}$, Telaga Sari, Purwodadi Kabupaten Pasuruan. Keterangan: A. Ikan Betina, B. Ikan Jantan, C. Sisik sikloid abdomen, D. Sisik sikloid daerah sirip ekor, E . Gonopodium ikan jantan, F \& G Struktur Gonopodium, H.

Pigmentasi jantan

\section{Karakteristik:}

Jumlah jari-jari sirip punggung D7 (jari-jari ke 1 dan 2 tidak bercabang) (Gb 8A); jumlah jari-jari sirip dada P12-15 (jari-jari 1 dan terakhir tidak bercabang); jumlah jari-jari sirip anal ikan betina A9-10 (Jari-jari 1 dan terakhir tidak bercabang); jumlah jari-jari sirip 


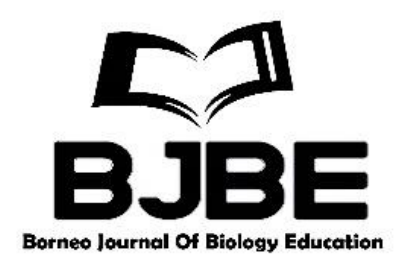

ekor C20-22; jumlah jari-jari sirip perut V6, jari-jari ke-5 lebih panjang dan bengkok; jumlah sisik lateralis LL 26-28; dan jumlah sisik transversalis Ltr 3 1/2.1.3 1/2. Karakter anatomi ikan Poecilia sp. sebagai berikut: bentuk sirip ekor rounded pada ikan betina, dan meruncing pada ikan jantan; tipe sisik sikloid: sisik pada bagian kepala memiliki hanya garis kosentris (Gb.8C), sisik pada bagian abdomen memiliki garis konsentris dan radier (Gb.8D\&E); tipe tulang ekor ikan isosercal; bentuk tubuh ikan compressed; tipe letak mulut superior; posisi sirip punggung lebih awal daripada sirip anal (ikan betina); dan posisi gonopodium lebih awal daripada sirip punggung (ikan jantan).

\section{Pola Warna:}

Ikan jantan dan ikan betina memiliki pola warna tubuh yang sangat berbeda. Tubuh ikan betina memiliki melanosit yang memberikan warna hitam. Ikan jantan memiliki banyak pola warna (Gb.8.A). Individu jantan satu dengan yang lainnya mempunyai pola warna yang berbeda-beda, akan tetapi terdapat pigmen tertentu yang sering muncul pada setiap individu jantan, yaitu spot berwarna hitam dengan warna metalik dan smear kuning disekelilingnya (Gb.8.A), panah warna merah. Pada umumnya ikan jantan memiliki 2 sampai 3 spot. Seluruh tubuh ikan memiliki pigmen yang sama yaitu kuning, hitam, dan metalik. Warna-warna ini berupa smear, dengan pola acak yang menyebar diseluruh tubuh ikan mulai dari badan sampai ekor. Warna yang sering muncul pada bagian sirip ekor yaitu hitam dan terletak pada bagian perifer.

\section{Distribusi:}

Polandia, Rusia, Albania, dan Jepang, Telaga Sari, Purwodadi, Kabupaten Pasuruan

Karakter khusus anggota famili Poeciliidae adalah struktur gonopodium yang merupakan modifikasi jari-jari ke 3,4,5 sirip anal. Setiap spesies memiliki karakter gonopodium yang berbeda (Rahayu et al., 2010). Pembeda diantara ikan Famili Poeciliidaeyang ditemukan antara lain: jenis 1 dan 2 memiliki kesamaan pada jumlah jari-jari sirip dorsal 14-15; memiliki distal serrae berjumlah 3, memiliki blade yang tajam; ramus kaku; jumlah proxsimal serrae pada gonopodium jari-jari 4p 7-8; ikan jantan memiliki pemanjangan sirip ekor pada bagian ventral yang berbentuk seperti pedang dengan warna kehitaman. Berdasarkan karakter morfologi jenis 1 dan 2 diduga termasuk genus Xiphophorus, spesies Xiphophorus hellerii Heckel. Jenis 2 memiliki pigmentasi melanosit lebih banyak daripada karotenoid dan memiliki purin pada bagian abdomen Xiphophorus hellerii (Abu-abu), sedangkan jenis 1 memiliki pigmentasi karotenoid lebih banyak daripada melanosit baik dibagian abdomen maupun sirip Xiphophorus hellerii (Oranye)

Jenis 3 dan 4 memiliki kesamaan pada tidak adanya pemanjangan sirip ekor; jari-jari ke-5 pada sirip perut lebih panjang dan bengkok; mempunyai gonopodium palp pada jari-jari ke-3 gonopodium. Perbedaan dari kedua sampel tersebut adalah jenis 3 memiliki jumlah jarijari sirip dorsal 10-11; memiliki kait bermembran dan jaringan bermembran, memiliki retrose serrae, sedangkan jenis 4 memiliki jari-jari ke-3 gonopodium berbentuk seperti duri, jumlah jari-jari sirip dorsal 7. Berdasarkan karakter tersebut jenis 3 dan 4 diduga termasuk genus Poecilia, spesies Poecilia mexicana Steindachner, sedangkan ikan jenis 4 diduga Poecilia reticulata Peter.

\section{B. Klasifikasi Ikan Mudskipper Berdasarkan Karakter Morfologi}

Analisis fenetik dilakukan dengan menggunakan 35 karakter data hasil analisis morfologi ikan Famili Poeciliidae yang telah di karakterisasi dengan menggunakan metode 


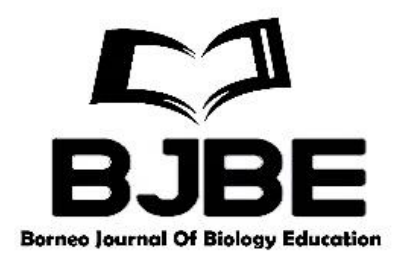

UPGMA. Berdasarkan karakter morfologi yang dimiliki oleh masing-masing ikan, kemudian dihitung nilai koefisien asosiasinya. Nilai tersebut dapat ditentukan dengan cara membandingkan karakter diagnostik yang terdapat pada semua spesies ikan yang termasuk dalam Operational Taxonomic Unit (satuan taksonomi operasional) terlihat pada fenogram (Gambar 9). Dendogram hasil analisis morfologi dianalisis dengan menggunakan software NTSYSpc V2.02i diperoleh dua kelompok percabangan yaitu: klad Xiphoporus helleriiabuabu dan Xiphoporus helleriioranye dengan Poecilia mexicana dan Poecilia reticulata membentuk percabangan yang berbeda. Belum ada pembagian klasifikasi berdasarkan karakter morfologi sebelumnya terhadap ikan Famili Poeciliidae yang ditemukan ini berdasarkan dari karakter morfologi. Variasi pengelompokan pada level subklad umum terjadi pada kajian taksonomi ikan jika menggunakan marka yang berbeda-beda di setiap pengelompokannya. Semakin menunjukkan variasi dalam pendeferensiasian marka yang digunakan, akan semakin memperkaya sumber referensi pada pengelompokkan ikan Famili Poeciliidae ini, dikarenakan sampai sekarang klasifikasinya masih rancu. Sehingga dengan pengelompokkan berdasarkan karakter morfologi secara lengkap akan memperjelas status taksonomi ikan Famili Poeciliidae di Jawa Timur.

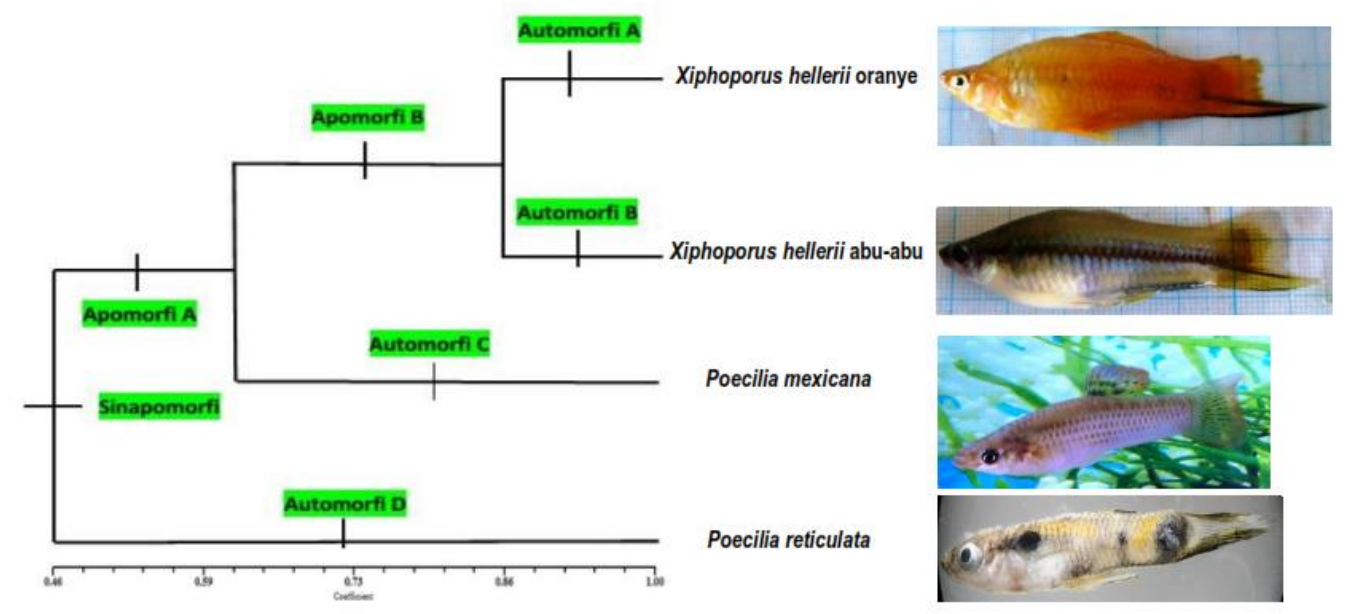

Gambar 9. Dendogram ikan famili Poeciliidae berdasarkan karakter morfologi

Kelompok I dengan koefisien asosiasi (S) 92\% terdiri atas clade Xiphoporus helleri abu-abu dan Xiphoporus helleri oranye. Karakter automorphi pembeda diantara keduanya yaitu Jenis Xiphoporus helleri abu-abu memiliki pigmentasi melanosit lebih banyak daripada karotenoid dan memiliki purin pada bagian abdomen Xiphophorus hellerii (oranye), sedangkan jenis Xiphoporus helleri abu-abu memiliki pigmentasi karotenoid lebih banyak daripada melanosit baik dibagian abdomen maupun sirip Xiphophorus hellerii (Oranye) dengan ciri diagnostik struktur gonopodium yang sama yaitu adanya cakar pada ujung terminal gonopodium jari-jari 5a yang berbentuk panjang dan lebar. Karakter tersebut khas dimiliki oleh genus Xiphophorus (Gordon \& Rosen, 1951). Ikan jenis 3 dan 4 memiliki kesamaan karakter dengan genus Poecilia yaitu adanya gonopodium palp (Meyer et al., 2000; Poeser et al., 2005). Selain itu, jenis 1 dan 2 memiliki kait berbentuk seperti bulan sabit pada gonopodium jari-jari ke-3; memiliki distal serrae berjumlah 3, blade yang tajam; ramus yang kaku mirip dengan karakter gonopodium ikan Xiphophorus helleri (Gordon \& Rosen, 1951).

Karakter automorfi Poecilia mexicana dengan nilai koefisien asosiasi (S) 87\% yaitu memiliki ciri khas adanya kait bermembran dan jaringan bermembran, memiliki retrose serrae, kait pada ujung jari-jari 5a berbentuk pendek dan kecil, terdapat distal platform pada gonopodium jari-jari ke-3. Sedangkan, karakter automorfi memiliki karakteristik jari-jari ke-3 


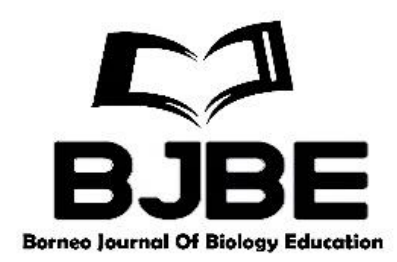

gonopodium berbentuk seperti duri, ujung gonopodium jari-jari $5 \mathrm{p}$ memiliki kait yang panjang dan pendek. Karakter tersebut mirip ikan Poecilia reticulata (Poeser et al., 2005) dengan nilai dengan nilai koefisien asosiasi (S) $84 \%$.

Mayr dan Ashlock (1991) menyatakan bahwa karakter morfologi menggambarkan sebagian besar dari sifat genotip suatu organisme yang diperbandingkan. Karakter morfologi digunakan untuk melengkapi dan menambah karakter diagnostik suatu spesies. Hubungan kekerabatan ikan perlu dipelajari untuk mengetahui kedekatan antara spesies ikan yang terdapat di suatu perairan, dan juga memberikan informasi ilmiah dalam bidang taksonomi (Tjitrosoepomo, 1993).

Berdasarkan karakter morfologinya, jenis-jenis ikan yang ditemukan termasuk dalam tingkatan taksonomi: Kingdom Animalia, Phylum Chordata, Class Actinopterygii, Order Cyprinodontiformes, Family Poeciliidae, Sub Family Poeciliinae (Kerrigan, 1934; www.ITIS.org). Perbedaan dari Xiphoporus sp. terletak pada pola warnanya saja. Ikan Xiphoporus 1 memiliki warna khas oranye, sedangkan ikan Xiphoporus 2 memiliki ciri khas berwarna abu-abu. Jenis ini termasuk ikan Southern swordtail (Kallman \& Kazianis, 2006), genus Xiphophorus, spesies Xiphophorus hellerii Heckel (Myron \& Eric, 1951; Kallman\& Kazianis, 2006; Maurice et al., 1993; www.ITIS.org). Jenis 3 dan jenis 4 termasuk genus Poecilia (Schories et al., 2009; Meyer et al., 2004; Meyer et al., 2000; Ghedoti, 2005). Jenis 3 termasuk ikan Mollenesia, spesies Poecilia mexicana Steindachner (Meyer et al., 2000; Meyer et al., 2004; www.ITIS.org). Jenis 4 termasuk ikan common guppy (Poeser et al., 2005), spesies Poecilia reticulata Peter (Schories et al., 2009; Poeser et al., 2005; Maurice et al., 1993; www.ITIS.org).

\section{Pengelompokkan ikan Famili Poeciliidae berdasarkan karakter morfometrik}

Analisis lebih lanjut untuk memperkuatstatus taksonomi ikan famili Poeciliidae yang ditemukan di Telaga Sari Pasuruandilakukanpengukuran karakter morfometrik denganmenggunakan 35 karakter terpilih, diantaranya ukuran Panjang gonopodium yang merupakan pembedautama spesies diantara golongan ikan famii Poeciliidae yang ditemukan. Kisaran panjang standart spesiesXiphophorus helerii $5.91 \mathrm{~cm} \pm 0.02$; Poecilia mexicana 4.82 \pm 0.19 dan Poecilia reticulata $2.37 \pm 0.02$. Berdasarkan kisaran panjang standarttersebut, diasumsikan sudah mempunyaikarakter morfologi yang sudah mapan. Roberts(1993) melaporkan bahwa holotype untuk jenisini seperti: Xiphoporus hellerii mempunyaipanjang standar $590 \mathrm{~mm}$; Poecilia reticulata $235 \mathrm{~mm}$ yang disimpan di MNHN(Museum National de Histoire Naturelle)Belanda.

Hasil pengukuran yang diperoleh dianalisis menggunakan analisis diskriminan untuk memperjelas karakter pembeda utama antara ikan Poeciliidae yang ditemukan pada lokasi tersebut dan membedakan antar jenis (Kendall, 1975 dan Morrison, 1978). Hasil pengukuran karakter morfometrik merupakan salah satu parameter yang dapat digunakan. Hal ini dikarenakan ciri morfometrik merupakan ciri taksonomik saat mengidentifikasi ikan. Setiap spesies ikan memiliki ukuran mutlak berbeda-beda (Affandi dkk., 1992). Hasil analisis diskriminan terhadap data morfometrik dilakukan melalui dua tahap, yaitu: tahap 1, yaitu sejumlah 35 karakter morfometrik diuji, tahap 2 yang dilakukan yaitu pengujian untuk menentukan karakter pembeda utama yang paling berpengaruh. Pengelompokkan ikan Poeciliidae dibedakan berdasarkan lima karakter utama terpilih dari 35 karakter yang diuji menggunakan Wilks Lamda dengan nilai signifikasi 0.000 yang artinya berbeda sangat nyata (sangat signifikan). Sedangkan, 30 karakter morfometrik yang lain tidak membedakan secara nyata antara ikan Mudskipper yang ditemukan. Kelima karakter terpilih tersebut adalah SL: 


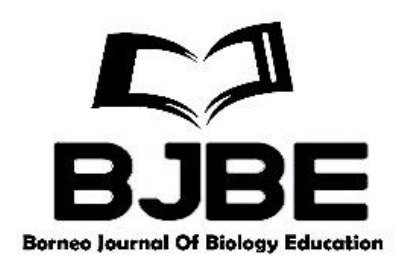

panjang standart, Panjang kepala, Panjang gonopodium, Panjang perpanjangan sirip ekor, dan Panjang sebelum sirip dorsal (Tabel 1).

Tabel 1. Karakter morfometrik pembeda diantara Famili Poeciliidae

\begin{tabular}{lcccc}
\hline \multicolumn{1}{c}{ Karakter } & $\begin{array}{c}\text { Xiphoporus } \\
\text { helleri } \\
\text { (Oranye) }(\mathrm{cm})\end{array}$ & $\begin{array}{c}\text { Xiphoporus helleri } \\
(\text { Abu-abu) }(\mathrm{cm})\end{array}$ & $\begin{array}{c}\text { Poecilia } \\
\text { mexicana }(\mathrm{cm})\end{array}$ & $\begin{array}{c}\text { Poecilia } \\
\text { reticulata }(\mathrm{cm})\end{array}$ \\
\hline $\begin{array}{l}\text { Panjang standart } \\
\text { (SL)** }\end{array}$ & $5.91 \pm 0.02$ & $4.85 \pm 0.25$ & $4.82 \pm 0.19$ & $2.37 \pm 0.02$ \\
$\begin{array}{l}\text { Panjang kepala } \\
\text { (HdL)** }\end{array}$ & $1.19 \pm 0.02$ & $1.24 \pm 0.02$ & $1.00 \pm 0.02$ & $0.33 \pm 0.01$ \\
$\begin{array}{l}\text { Panjang } \\
\text { gonopodium** }\end{array}$ & $1.18 \pm 0.01$ & $1.18 \pm 0.01$ & $0.77 \pm 0.01$ & $0.53 \pm 0.01$ \\
$\begin{array}{l}\text { SWL (length of sword) } \\
\begin{array}{l}\text { Panjang sebelum sirip } \\
\text { dorsal (PreDL)** }\end{array}\end{array}$ & $0.09 \pm 0.01$ & $1.02 \pm 0.01$ & 0 & 0 \\
\hline
\end{tabular}

Brown dan Gibson (1983) dalam Haryono (2001) menyatakan bahwa setiap spesies mempunyai sebaran geografi tertentu yang dikontrol oleh kondisi fisik lingkungannya. Sebaran dan variasi morfometrik yang muncul merupakan respon terhadap lingkungan fisik tempat hidup spesies ikan tersebut. Variasi karakter morfometrik dapat disebabkan oleh perbedaan faktor genetik dan lingkungan. Tahap Pengujian genetik dapat menggambarkan perbedaan basa nukleotida antar spesies ikan maupun populasi ikan dan perbedaan lingkungan geografi di masing-masing lokasi. Oleh karena itu, perbedaan jenis ikan dan populasi ikan berdasarkan variasi morfometri perlu diuji dengan bukti genetik untuk mengkonfirmasi bahwa variasi tersebut juga menggambarkan isolasi reproduksi dan bukan karena perbedaan lingkungan (Tzeng, 2000). Hal ini sejalan dengan pendapat Shaklee \& Tamaru (1981) yang mengatakan ikan bertulang sejati (Osteichtyes) menunjukkan variasi karakter morfologis pada letak geografis yang berbeda. Perbedaan tersebut ditandai dengan adaptasi lingkungan dan variabel biologi dari masing-masing lokasi.

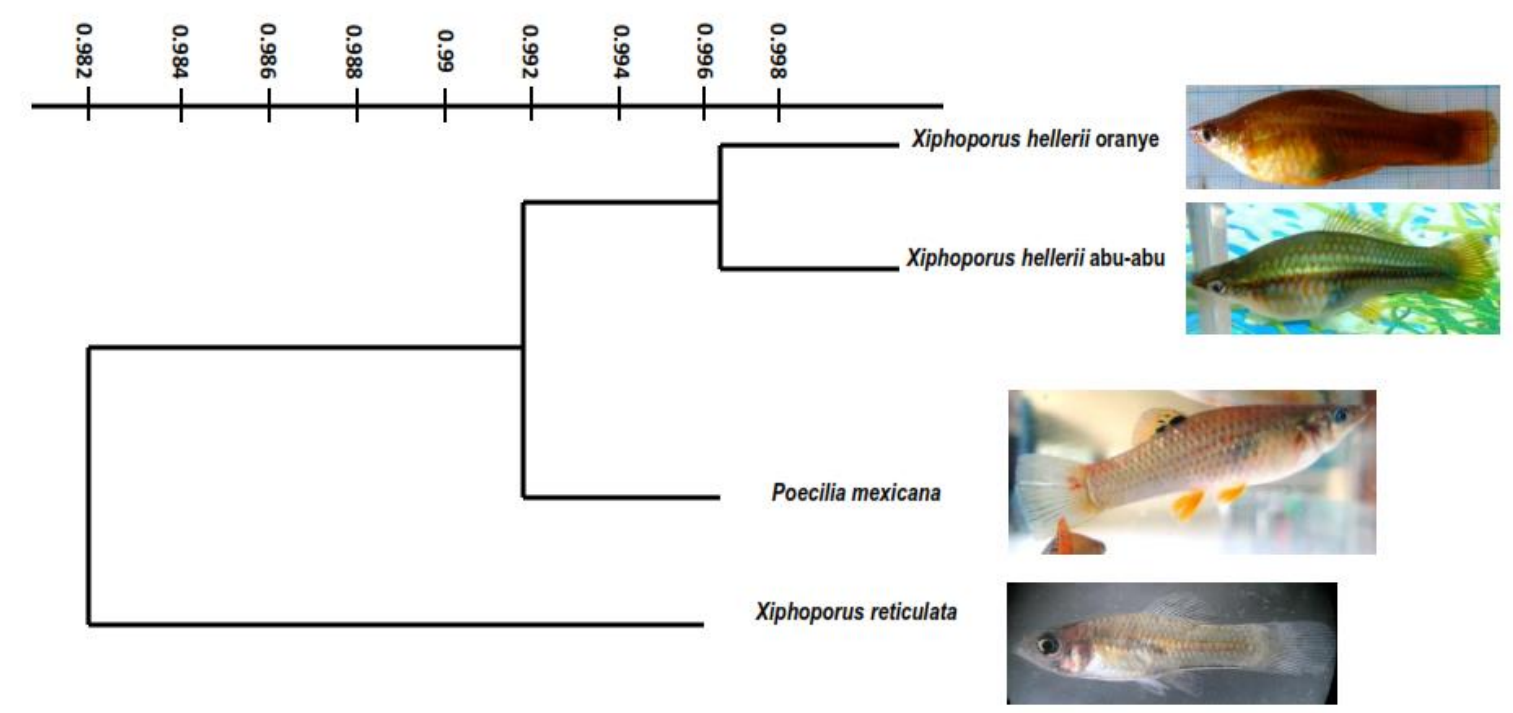

Gambar 10. Dendogram ikan famili Poeciliidae berdasarkan lima karakter terpilih 


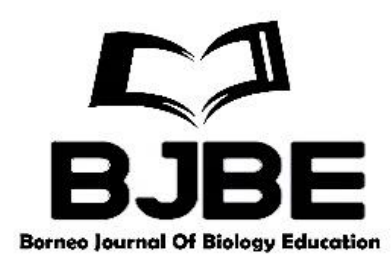

Penentuan hubungan kekerabatan selanjutnya dianalisis menggunakan Analisis Komponen Utama (PCA) berdasarkan 5 karakter morfometrik yang paling berpengaruh, Seperti yang dikemukakan oleh Bengen (2000) bahwa Analisis Komponen Utama dapat digunakan untuk mempelajari matriks data dari sudut pandang kemiripan antar individu. Semakin mirip atau jarak yang dekat suatu individu maka semakin dekat hubungan kekerabatannya. Analisis dendogram berdasarkan jarak Euclidian menunjukkan tiga pengelompokkan berdasarkan karakter morfometrik pembeda utama diantara spesies yang ditemukan. Dendogram yang terbentuk menunjukkan dua kelompok ikan famili Poeciliidae yang ditemukan, yaitu klad pertama terdiri atas klas Xiphoporus, Pecilia yang terbagi menjadi 2 clade yaitu Poecilia mexicana dan Poecilia reticulata. Hal ini sesuai dengan pengelompokkan berdasarkan analisis morfologi yang membentuk 2 clade antara Genus Xiphoporus dan Poecilia. Analisis diskriminasi terbentuk dari lima karakter terpilih pembeda utama yang mengindikasikan bahwa keempat spesies terdeferensiasi berdasarkan karakter morfometrik.

\section{Kesimpulan}

Pada penelitian ini ditemukan 3 jenis ikan Famili Poeciliidae yaitu Xiphoporus helleri, Poecilia mexicana dan Poecilia reticulata. Dendogram hasil analisis morfologi diperoleh dua kelompok percabangan clade taksa yaitu Xiphoporus dan Poecilia. Hasil analisis diskriminan terhadap karakter morfometrik yang membedakan antar spesies yang ditemukan yaitu SL: panjang standart, Panjang kepala, Panjang gonopodium, Panjang perpanjangan sirip ekor, dan Panjang sebelum sirip dorsal.

\section{Ucapan Terima Kasih}

Penulis mengucapkan terimakasih kepada masyarakat sekitar Telaga Sari, Purwodadi, Kabupaten Pasuruan yang telah membantu jalannya penelitian dan Prof. John Kress, Ph.D yang telah memberikan masukan terkait hasil cladogram kekerabatan ikan Famili Poeciliidae yang terbentuk.

\section{Daftar Pustaka}

Affandi R, Djadja S.S, Rahardjo M.F, Sulistiono. 1992. Iktiologi, suatu pedoman kerja laboratorium. IPB. $344 \mathrm{hlm}$.

Canonico, G.C., Arthington, A., McCray, J.K., \& Thieme, M.L. 2005. The effects of introduced tilapias on native biodiversity. Aquatic Conservation: Marine and Freshwater Ecosystems, 15: 463-483. https://doi.org/10.1002/aqc.699

Dudgeon, D., Arhtington, A.H., Gessner, M.O., Kawabata, Z.I., Knowler, D.J., Leveque, C., Naiman, R.J., Prieur-Richards, A.H., Soto, D., Stiassny, M.L.J., \& Sullivan, C.A. 2006. Freshwater biodiversity: importance, threats, status and conservation challenges. Biological Review, 81:163-182. DOI: 10.1017/S1464793105006950.

Ghedotii, M.J. 2000. Phylogenetic Analysis and Taxonomy of The Poeciliidae Fishes (Teleostei: Cyprinodontiformes). Zoological Journal Linn. Soc. 130: 1-53. https://doi.org/10.1006/zjls.1999.0213. 


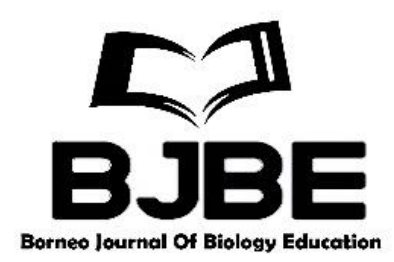

Gordon., Myron., Rosen. \& Eric, D. 1951. Genetics of Species Differences in The Morphology of The Male Genitalia of Xiphopohorin Fishes. American Museum of Natural History, 95: 460-464.

Hrbek T, Seckinger J, Meyer A (2006) A phylogenetic and biogeographic prespective on the evolution of Poeciliid fishes. Molecular Phylogenetics and Evolution 43: 986-998.

Kerrigan, A. M. 1934. The Inheritance of the Crescent and Twin Spot Marking in Xiphophorus hellerii. Genetic, 19: 581.

Kottelat M, Whitten AJ. 1993. Freshwater fishes of western Indonesia and Sulawesi. Periplus Editions, Indonesia.

Lee, C.E. 2002. Evolutionary genetics of invasive species. Trends in Ecology and Evolution, 17: 386- 391. https://doi.org/10.1016/S0169-5347(02)02554-5.

Lintermans, M. 2004. Human-assisted dispersal of alien freshwater fish in Australia. New Zealand Journal of Marine and Freshwater Research, 38: 481-501. https://doi.org/10.1080/00288330.2004.9517255.

Lucinda, P. H. F. \& Reis, R. E. 2005. Systematics of the subfamily Poeciliinae Bonaparte (Cyprinodontiformes:Poeciliidae), with an emphasis on the Tribe Cnesterodontini Hubbs. Neotropical Ichthyology, 3: 1-60. http://dx.doi.org/10.1590/S167962252005000100001.

Lucinda, P. H. F. 2003. Family Poeciliidae, Check List of The Freshwater Fishes of South and Central America. Edipucrs, Porto Alegre, Brazil, pp: 555-581.

Maurice, K., Whitten, A. J., Kartikasari, S. N. \& Wirjoatmodjo, S. 1993. Ikan Air Tawar Indonesia Bagian Barat dan Sulawesi. Jakarta: Periplus Edition.

Mayr E, Ashlock PD. 1991. Principles of systemic zoology. Singapore: McGraw-Hill Book Co.

Meyer, M. K. \& Radda, A. C. 2000. Notes on The Subgenus Mollienesia LeSueur, 1821, with a Description of a New Species of Poecilia Bloch \& Scheinder, 1801 (Cyprinodontiformes:Poeciliidae) from Venezuela. Ann Naturhist, 102B: 75-81.

Meyer MK, Schneider K, Radda AC, Wilde B, Schartl M (2004) A new species of Poecilia, subgenus Mollienesia, from Upper Rio Cahabon System, Guatemala, with remarks on the nomenclature of Mollienesia petenensis Gunter, 1866. (Teleostei: Cyprinodontiformes: Poeciliidae). Zoologische Abhandlungen, 54: 145-154.

Parenti, L. R. 1981. A Phylogenetic and Biogeographic Analysis of Cyprinodontiformes Fishes (Teleostei, Atherinomorpha). Nature, $168: 335-557$.

Poeser, F. N., Kempkes, M., \& Isbrücker, I. J. H. 2005. Description of Poecilia (Acanthophacelus) wingei n. sp. from the Paria Peninsula, Venezuela, including notes on Acanthophacelus Eigenmann, 1907 and other subgenera of Poecilia Bloch and Schneider, 1801 (Teleostei, Cyprinodontiformes, Poecilidae). Contributions to Zoology 74: 97-115.

Pez. 2009. Poeciliidae. (Online), http://atlas.drpez.org/endler, diakses tanggal 10 Juli 2019.

Rahayu, D. A., Jannah, M., Winaris, N. \& Listyorini, D. 2010. The Phylogenetic of Gatul Fish (Xiphoporus sp.) in Sari Lake Pasuruan Regency. Proceedings of the Association for Tropical Biology \& Conservation 2010 Meeting, Bali. Indonesia.

Rahayu, D.A., Ibrohim \& Listyorini, D. 2013. Morphological study for identification improvement of Poeciliidae Family Based on Gonopodium Structures and Morphometrics Analysis. The Journal of Tropical Life Science. Vol 3 (1) pp. 91-95

Saanin H. 1984. Taksonomi dan Kunci Identifikasi Ikan Jilid 1 dan 2. Bina Cipta: Jakarta. 


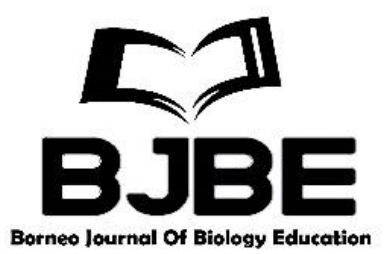

Semmens, B.X., Buhle, E.R., Salomon, A.K., \& Pattengill-Semmens, C.V. 2004. A hotspot of non-native marine fishes: evidence for the aquarium trade as an invasion pathway. Mar. Ecol. Prog. Ser., 266:239-244. DOI: 10.3354/meps266239.

Schories, S., Meyer, M. K. \& Schartl, M. 2009. Description of Poecilia (Acanthophacelus) obscura n. sp., (Teleostei: Poeciliidae), a new Guppy Species From Western Trinidad, with Remarks on Poecilia wingei and the status of the "Endler's guppy". Zootaxa, 2266: 35-50.

Tamaru, C. S., Cole, B. \& Bailey,R. 2001. A Manual for Commercial Production of the Swordtail Xiphoporus helleri. Education Journal, 128. DOI: 10.13140/RG.2.1.1040.3289.

Tjitrosoepomo G. 1993. Taksonomi umum. Yogyakarta: GadjahMada University Press. www. ITIS.org. 2011. Integrated Taxonomic Information System.

www. Fishbase.org. 2011. A Global Information System on Fishes. 